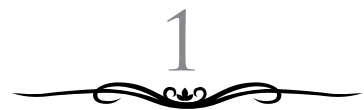

\title{
MENGGAGAS PERPUSTAKAAN TERAKREDITASI DI PERGURUAN TINGGI ISLAM
}

\author{
Fuad Riyadi \\ STAIN Kudus, Jawa Tengah, Indonesia \\ Abuhabib12344@gmail.com
}

\begin{abstract}
In education, we need library. Without library, what should the student of university do? It must be exist in the university's life. What can be the university without the library? Mainly, the library in university becames the heart of university. The three activities based on "Tri Dharma Perguruan Tinggi" always spend the library to live, grow and optimize. The university library is a library that is incorporated in university, managed entirely by the university concerned with the goal of serving business university to achieve specific goals and objectives of university education in general.An accredited library in the university in something essential and the way to do best for any users. By completing the standard of service, the standard of proficiency, the standard of management, and so on, will keep the library and the users and anyone who need the library run in well and in comfort.
\end{abstract}

Keywords: library,accredited library, university

\begin{abstract}
Abstrak
Dalam dunia pendidikan, kita membutuhkan perpustakaan. Tanpa perpustakaan, apa yang bisa dilakukan oleh mahasiswa? Bagaimanapun juga perpustakaan harus ada dalam kehidupan sebuah perguruan tinggi. Apa jadinya sebuah perguruan tinggi
\end{abstract}


tanpa perpustakaan? Menjadi aneh, absurd dan tidak layak manakala sebuah perguruan tinggimenafikan perpustakaan. Pada pokoknya, perpustakaan menjadi jantung di sebuah perguruan tinggi. Apa yang disebut Tri Dharma Perguruan Tinggi selalu lekat dan butuh akan keberadaan perpustakaan, untuk bisa hidup, tumbuh dan berkembang secara maksmial. Perpustakaan perguruan tinggi merupakan perpustakaan yang berinkorporasi di dalam perguruan tinggi, dikelola secara menyeluruh oleh perguruan tinggi, dengan suatu atensi pada tujuan untuk melayani kepentingan perguruan tinggi dalam meraih tujuan yang spesifik dan target pendidikan pada perguruan tinggi secara umum. Sebuah perpustakaan terakreditasi di perguruan tinggi menjadi suatu tuntutan dan idealnya sebuah perpustakaan dalam memberikan layanan prima kepada para pengguna. Dengan memenuhi standar layanan, standar profesionalitas, standar pengelolaan, dan lainnya, perpustakaan dapat berusaha untuk senantiasa menjaga kualitas, yang di dalam perjalanannya, sangant dibutuhkan oleh siapapun baik civitas akademika, khalayak dan lainnya. Menggagas perpustakaan perguruan tinggi yang terakreditasi merupakan sebuah kenyataan yang harus dihadapi dan diwujudkan oleh semua elemen perguruan tinggi. Dengan demikian, kebaikan dan kenyamanan perpustakaanakan senantiasa dapat terselenggara.

Kata kunci: Perpustakaan,perpustakaan terakreditasi, perguruan tinggi

\section{A. Pendahuluan}

Dunia pendidikan memberikan ruang bagi setiap individu untuk melakukan perbaikan, penyiapan diri, dan pengembangan potensi yang telah Allah Ta'ala titipkan. Siapapun, tanpa terkecuali, mendapatkan kesempatan yang sama dalam hal pendidikan. Meski secara teknis, orang sering berbenturan dengan persepsi atau faktabahwa pendidikan itu mahal, pendidikan itu komersil, pendidikan itu berat, atau lainnya.

Pendidikan Islam memberikan sebuah tawaran nyata bahwa untuk menuju kepada pendidikan yang berkualitas, tidak harus dengan biaya yang besar akan menghasilkan pendidikan 
yang berkualitas.Pendidikan Islam yang dilaksanakan dalam suatu sistem memberikan kemungkinan berprosesnya bagianbagian menuju ke arah tujuan yang ditetapkan sesuai ajaran Islam.Sebagai bagian yang tak terpisahkan dari pendidikan adalah sarana dan prasarana.Keberadaan sarana dan prasarana menjadi unsur penting yang tidak dapat dipisahkan dari pendidikan. Karena setiap pembelajaran dan jalannya pendidikan tidak bisa meninggalkan sarana dan prasarana.Sarana dan prasarana ini menjadi unsur utama bagi suksesnya pendidikan.Salah satu sarana itu adalah perpustakaan.

Membincangkanperpustakaan sejatinya bukan masalah pribadi, atau kelompok, atau masalah segelintir orang.Tapi berbicara terntang perpustakaan adalah berbicara tentang kebutuhan manusia untuk mengembangkan diri, memajukan dan menggiatkan atmosfir keilmuan di tengah-tengah arus kapitalisme dan materialisme.

Perguruan tinggi sebagai tempat menempa ilmu pengetahuan, tentunya, sangat membutuhkan perpustakaan. Perpustakaan menjadi sumber belajar bagi civitas akademika, mahasiswa dan dosen.Urgensi perpustakaan dalam perguruan tinggi dapat dilihat dalam upaya dan kegiatan yang mengarah pada intelektualitas, skill dan afektivitas.

Masalah FundamentalPada era kekinian, perpustakaan perguruan tinggi dituntut untuk memenuhi StandarNasional Perpustakaansesuai amanah Undang-undang Nomor 43 Tahun 2007 Perpustakaan Pasal 24 ayat a. mengamanatkan bawa penyelenggaraan Perpustakaan Perguruan Tinggi memenuhi Standar Nasional Perpustakaan dengan memperhatikan Standar Nasional Pendidikan.Baik standar layanan standar pustakawan, standar manajemen dan lainnya.Perguruan tinggi memiliki tanggung jawab untuk mengembangkan perpustakaannya dan meningkatkan performanya Tinggi dengan mewujudkan perpustakaan yangmemenuhi Standar Nasional Perpustakaan Perguruan Tinggi atau terakreditasi 


\section{B. Pembahasan}

\section{Perpustakaan di Perguruan Tinggi}

Perpustakaan perguruantinggi, sebagaisebuahinstitusi,agar kualitasnya terukur, maka perlu dilakukan penilaian (akreditasi) terhadap penyelenggaraannya. Suatu penilaian perpustakaan perguruan tinggi oleh lembaga independen yang didasarkan pada suatu acuan penilaian yang bersifat objektif dan transparan kiranya akan menjawab tingkat kualitas perpustakaanperguruan tinggi. ${ }^{1}$

Keberadaan perpustakaan pada setiap Penyelenggaraan dan pendirian perguruan tinggi seperti, Universitas, Institut, sekolah tinggi, politeknik, dan akademik yang di dalamnya terdapat fakultas, Jurusan dan Program adalah mutlak ada. Berdasarkan Peraturan Menteri Pendidikan dan Kebudayaan Republik Indonesia Nomor 17 Tahun 2014 tentang Pendirian perguruan tinggi menyatakan bahwa persyaratan minimal untuk universitas, tenaga perpustakaan dengan kualifikasi d3 perpustakaan 2 orang,dan S1 Perpustakaan 1 orang dan persyaratan minimal sarana prasarananya adalah harus ada ruang perpustakaan. Lebih tegas lagi, bahwa ketentuan penyelenggaraan perpustakaan perguruan tinggi menurut undang-undang nomor 43 pasal 24 adalah: 1 . Setiap perguruan tinggi menyelenggarakan perpustakaan yang memenuhi standar nasional perpustakaan dengan memperhatikan standar nasional pendidikan (ayat 1) 2. Perpustakaan sebagaimana dimaksud pada ( ayat 1) memiliki koleksi, baik jumlah judul maupun jumlah eksemplarnya, yang mencukupiuntukmendukung pelaksanaan pendidikan, penelitian, dan pengabdian kepada masyarakat (ayat 2), 3. Perpustakaan perguruan tinggi mengembangkan layanan perpustakaan berbasis teknologi informasi dan komunikasi (ayat 3), 4. Setiap perguruan tinggi mengalokasikan dana untuk pengembangan perpustakaan sesuai dengan peraturan perundang-undangan guna memenuhi

${ }^{1}$ Perpustkaan Nasioanal Republik Indonesia, "Menggagas Kualitas Perpustakaan Perguruan Tinggi”, perpusnas.go.id/magazine-kind/menggagaskualitas-perpustakaan-perguruan-tinggi/, diakses tanggal 22/09/2016 
standar nasional pendidikan dan standar nasional perpustakaan (ayat 4$){ }^{2}$

Menurut Suwarno, perpustakaan adalah sebuah ruangan, bagian sebuah gedung, ataupun gedung yang digunakan untuk menyimpan buku dan terbitan lainnya. Biasanya buku tersebut disimpan menurut tata susunan tertentu untuk digunakan oleh pembaca bukan untuk dijual.Perpustakaan dapat dikatakan baik jika telah memenuhi fungsi dan tujuan dari perpustakaan itu sendiri. ${ }^{3}$ Eksistensi perpustakaan memiliki tujuan yaitu: (1) mendorong dan mempercepat proses penguasaan teknik membaca para siswa, (2) membantu menulis kreatif bagi para siswa dengan bimbingan pustakawan dan guru, dan (3) menyediakan berbagai sumber informasi untuk kepentingan pelaksanaan kurikulum. Menurut Bafadal, fungsi dari perpustakaan itu sendiri terbagi menjadi lima yaitu: fungsi edukatif, fungsi informatif, fungsi rekreasi, fungsi riset atau penelitian, dan fungsi tanggungjawab administratif. ${ }^{4}$

Jadi,perpustakaan adalah tempat di mana terdapat koleksi pustaka yang diatur sedemikian rupa untuk keperluan tertentu sesuai dengan maksud diselenggarakannya pengum-pulan koleksi pustaka tersebut.Dalam pengertian tersebut di atas menunjukkan bahwa harus ada lima unsur untuk terpenuhinya syarat sebuah perpustakaan, yakni: (1) merupakan sebuah lembaga; (2) memiliki koleksi bahan pustaka, baik yang tercetak maupun yang terekam; (3) ada yang menggunakan koleksi bahan pustaka; (4) memiliki sarana perpustakaan diantaranya koleksi bahan pustaka, tempat mengatur bahan pustaka, pencatatan/administrasi perpustakaan; dan (5) adanya pengelola perpustakaan yang menguasai di bidang perpustakaan atau pustakawan. Perpustakaan sebagai lembaga,

2 Ikhwan, pentingnya perpustakaan di perguruan tinggi, http:// perpustakaan.unram.ac.id/2015/ 11/10/ pentingnya- perpustakaan-diperguruan-tinggi/ diakses tanggal 29/9/2016.

${ }^{3}$ Wiji Suwarno, PengetahuanDasar Kepustakaan; Sisi Penting Perpustakaan dan Pustakawan.(Bogor: Ghalia Indonesia. 2010), hlm. 31.

${ }^{4}$ Ibrahim Bafadal, Pengelolaan Perpustakaan Sekolah.(Jakarta: Bumi Aksara, 2009) hlm. 7. 
mengandung pengertian bahwa suatu perpustakaan harus mempunyai status jelas sebagai lembaga.Perpustakaan harus mempunyai komponen utama yang mendukung pelaksanaannya, yaitu koleksi bahan pustaka yang tercetak maupun terekam. Perpustakaan diadakan untuk melayani para penggunanya, yang memiliki sarana ruangan/bangunan/gedung, rak tempat koleksi bahan pustaka, meja, kursi serta perlengkapan administrasinya. Perpustakaan dikelola oleh petugas perpustakaan yang melaksanakan kegiatan perpustakaan dengan jalan memberikan pelayanan kepada masyarakat sesuai dengan tugas lembaga induknya berdasarkan ilmu perpustakaan, dokumentasi dan informasi yang dimilikinya melalui pendidikan. ${ }^{5}$

Demikianlah, perpustakaan telah menjadi tempat bagi benda-benda penting yang dikategorikan sebagai koleksi perpustakaan.Dan koleksi perpustakaan itulah sejatinya barang berharga yang menjadi kebutuhan banyak pihak.Setidaknya, kebutuhan yang bersifat mendesak, ilmiah, dan kerja kognitif.

\section{a. Perpustakaan sebagai Sarana Edukasi}

Perpustakaan memberikan banyak manfaat bagi penggunanya. Setiap orang dapat menemukan buku-buku referensi bagi persoalan ilmiah, baik yang berhubungan dengan masalah sosial, politik, budaya, agama, dan lain-lain, yang kesemuanya bisa ditemukan dalam literatur yang tersedia.

Sebuah lembaga pendidikan sangat butuh sekali dengan keberadaan sebuah perpustakaan.Bahkan perpustakaan menjadi barometer suatu lembaga pendidikan.Orang menyebut bahwa perpustakaan yang baik menjadikan lembaga pendidikan itu dipandang baik.Dan sebaliknya, lembaga pendidikan yang tidak memperhatikan perpustakaan dapat berarti bahwa kualitas pendidikan yang ada rendah dan kurang berkualitas.

Dalam dunia pendidikan, buku terbukti berdaya guna dan bertepat guna sebagai salah satu sarana pendidikan dan sarana

${ }^{5}$ https://lokanmuko2.wordpress.com/2011/05/17/perananperpustakaan-sebagai-pusat-sumber-belajarpsb/, diakses tanggal 17/09/2016 
komunikasi.Dalam kaitan inilah perpustakaan dan pelayanan perpustakaan harus dikembangkan sebagai salah satu instalasi untuk mewujudkan tujuan mencerdaskan kehidupan bangsa. Perpustakaan merupakan bagian yang vital dan besar pengaruhnya terhadap mutu pendidikan.

Perpustakaan merupakan salah satu sarana sebagai sumber pembelajaran yang dapat menjadi sebuah kekuatan untuk mencerdaskan bangsa.Perpustakaan mempunyai peranan penting sebagai jembatan menuju penguasaan ilmu pengetahuan yang sekaligus menjadi tempat rekreasi yang menyenangkan dan menyegarkan.Perpustakaan memberi kontribusi penting bagi terbukanya informasi tentang ilmu pengetahuan.Sedangkan perpustakaan merupakan jantung bagi kehidupan aktifitas akademik, karena dengan adanya perpustakaan dapat diperoleh data atau informasi yang dapat digunakan sebagai dasar pengembangan ilmu pengetahuan.Untuk memperbaiki kondisi tersebut, perpustakaan harus menjadi sarana aktif/interaktif dan menjadi tempat dihasilkannya berbagai hal baru. ${ }^{6}$

Di dalam perpustakaan perguruan tinggi tersedia bahan pustaka baik fiksi maupun non fiksi.Adanya bahan pustaka tersebut mendidik para mahasiswa membiasakan diri untuk belajar mandiri tanpa bimbingan pendidik, baik secara individual maupun secara berkelompok.Dengan adanya bahan koleksi para mahasiswa dapat meningkatkan minat baca, menulis dan berkarya, sehingga teknik membaca, menulis serta berkarya para mahasiswa semakin lama semakin dikuasai dan dipahami.Selain itu di dalam perpustakaan perguruan tinggi terdapat buku-buku yang sebagian besar pengadaannya selalu disesuaikan dengan kurikulum yang diajarkan oleh para pendidiknya.Oleh karena itu sangat mendukung sekali terhadap kelancaran pembelajaran dan perkuliahan, disebabkan karena perpustakaan memiliki fungsi edukatif. ${ }^{7}$

${ }^{6}$ https://lokanmuko2.wordpress.com/2011/05/17/perananperpustakaan-sebagai-pusat-sumber-belajarpsb/, diakses tanggal 17/09/2016

${ }^{7}$ Azizah, "Peran Pustakawan dalam Membangun Citra Perpustakaan 


\section{b. Eksistensi Perpustakaan di Perguruan Tinggi}

Dalam sebuah ensiklopedi online disebutkan bahwa perpustakaan adalah koleksi sumber informasi dan lainnya,

"A library is a collection of sources of information and similar resources, made accessible to a defined community for reference or borrowing. It provides physical or digital access to material, and may be a physical building or room, or a virtual space, or both. A library's collection can include books, periodicals, newspapers, manuscripts, films, maps, prints, documents, microform, CDs, cassettes, videotapes, DVDs, Blu-ray Discs, e-books, audiobooks, databases, and other formats."

Sebagaimana kita ketahui, perpustakaan perguruan tinggi adalah jantung dari perguruan tinggi tersebut. Library is the heart of educational process. Idealnya, perguruan, perguruan tinggi yang baik haruslah memiliki perpustakaan yang baik.Begitu pula sebaliknya.Perguruan tinggi yang tidak baik perlu dicurigai memiliki perpustakaan yang tidak baik. ${ }^{9}$

Perpustakaan perguruan tinggi adalah perpustakaan yang berada pada lingkungan perguruan tinggi atau sekolah tinggi, akademi atau sekolah tinggi lainnya yang pada hakikatnya merupakan bagian integral dari suatu perguruan tinggi. Perpustakaan perguruan tinggi didirikan untuk menunjang pencapaian tujuan perguruan tinggi yang bersangkutan dalam melaksanakan Tri Dharma Perguruan Tinggi, yaitu pendidikan, penelitian, dan pengabdian kepada masyarakat.Untuk melaksanakan tugasnya itu, perpustakaan perguruan tinggi memilih, mengolah, mengoleksi, merawat, dan melayankan koleksi yang dimilikinya kepada para warga lembaga induknya pada khususnya dan masyarakat akademis pada umumnya. ${ }^{10}$

PTAIN di Kudus" dalam Jurnal Perpustakaan Libraria, volume 1, Nomor 2, Juli-Desember 2013, hal. 198

${ }^{8}$ https://en.wikipedia.org/wiki/Library, diakses tanggal 17/09/2016

${ }^{9} \mathrm{http}: / / w w w . a n n e a h i r a . c o m / p e r p u s t a k a a n$-perguruan-tinggi.htm, diakses tanggal 17/09/2016

${ }^{10} \mathrm{http}: / /$ ahmadaguskurniawan.blogspot.co.id/2012/12/pengertian- 
Sebagai sebuah jantung, perpustakaan perguruan tinggi menggerakkan dan mengaliri semua proses belajar-mengajar di perguruan tinggi. Perpustakaan seperti ini bukan hanya sekedar menunjang proses pendidikan, tetapi juga menjadi the source of information. ${ }^{11}$ Menurut Rusina Syahrial Pamuntjak perpustakaan perguruan tinggi adalah "Perpustakaan yang tergabung dalam lingkungan lembaga pendidikan tinggi, baik yang berupa perpustakaan universitas, perpustakaan fakultas, perpustakaan akademi, perpustakaan sekolah tinggi, maupun perpustakaan lembaga penelitian dalam lingkungan perguruan tinggi. Perpustakaan perguruan tinggi merupakan suatu unsur penunjang yang merupakan perangkat kelengkapan dibidang pendidikan, penelitian dan pengabdian kepada masyarakat.Setiap perguruan tinggi harus memiliki perpustakaan yang bertugas menunjang penyelenggaraan Tri Dharma Perguruan Tinggi yang disebut Unit Pelaksana Teknis.

Koleksi perpustakaan perguruan tinggi seyogyanya terdiri: a. Buku referensi baik referensi umum maupun untuk bidang studi kasus; b. Buku teks baik yang diperlukan oleh mahasiswa maupun dosen, baik yang di wajibkan untuk mata kuliah tertentu, maupun yang dianjurkan; c. Buku untuk pengembangan ilmu yang melengkapi dan memperkaya pengetahuan diluar bidang studi yang ditekuni; d. Majalah ilmiah; e. Penerbitan perguruan tinggi, baik penerbitan sendiri maupun penerbitan perguruan tinggi lainnya; f. Penerbitan pemerintah, terutama produk hukum yang berkaitan dengan perguruan tiggi; g. Laporan-laporan, terutama dari lembaganya sendiri; h. Skripsi, Tesis, Desertasi, terutama dari lembaganya sendiri. ${ }^{12}$

Jika perpustakaan telah eksis di sebuah perguruan tinggi, dan keberadaannya mendapat perhatian para pihak;

perpustakaan-perguruan-tinggi.html, diakses tanggal 17/09/2016

${ }^{11} \mathrm{http}: / / w w w . a n n e a h i r a . c o m / p e r p u s t a k a a n-p e r g u r u a n-t i n g g i . h t m$, diakses tanggal 17/09/2016

${ }^{12} \mathrm{http}$ ://ahmadaguskurniawan.blogspot.co.id/2012/12/pengertianperpustakaan-perguruan-tinggi.html, diakses tanggal 17/09/2016 
yang mengambil kebijakan, petugas perpustakaan, dan user, setidaknya akan menjadi sinyalemen bahwa tidak benar adanya ungkapan bahwa perpustakaan sebagai tempat pembuangan. Image yang sedemikian sengaja dibangun oleh orang-orang yang tidak bertanggung jawab.Suatu persepsi yang keliru dan tidak perlu diteruskan.

Untuk menjadikan perpustakaan dengan segala kebaikan dan manfaat yang dimiliki, diperlukan usaha keras dan kerja berbagai pihak untuk menghidupkan perpustakaan.Sehingga perpustakaan bukan sekedar kumpulan buku atau benda usang, namun perpustakaantelah berubah dan memiliki daya tarik tersendiri bagi orang-orang yang berkepentingan dan memiliki atensi terhadap perpustakaan.

\section{c. Perpustakaan Perguruan Tinggi Terakreditasi}

Ada yang berpendapat bahwa perpustakaan selalu diidentikkan dengan koleksi buku dan bahan cetakan lainnya. Anggapan ini tidak berlebihan karena asal istilah perpustakaan (library) adalah pustaka (libri), yang kedua kata tersebut berarti buku. Mayoritas koleksi yang ada di perpustakaan adalah bahan tercetak yakni buku, majalah, koran dan semua jenis koleksi lainnya. Namun demikian, saat ini, media penyimpan informasi sudah mulai bertambah banyak, tidak hanya terbatas pada bahan cetakan, atau cakram saja, tapi juga bahan-bahan digital. Perubahan media penyimpan informasi ini tidak ekstrim dalam artian biarpun media digital sudah tumbuh sangat cepat, namun tetap saja bahan cetakan tidak bisa ditinggalkan karena beberapa hal yaitu: bahan cetakan ringan dan mudah untuk dibawa ke mana-mana, tidak memerlukan penerangan kecuali bila kondisi ruangan gelap, tidak memerlukan alat bantu tertentu untuk membacanya, merupakan sumber yang merangsang imajinasi, mudah dalam penyimpanan, dapat ditulisi, dan masih banyak keunggulan lainnya. ${ }^{13}$

Dalam redaksi yang lain, akreditasi adalah:"Accreditation is a voluntary system of quality control in higher education, based

13 Bahrul Ulumi, "Institutional Repository Perguruan Tinggi" dalam Jurnal Perpustakaan Libraria, volume 1, Nomor 1, Januari-Juni 2013. 
on non-governmental, external, peer evaluation of educational institutions and programs. Its purposes are to ensure that education by the program or institution meets appropriate levels of quality and integrity, based on criteria adopted by the accrediting body, and through the review process, to improve the quality of education. Thus, accreditation is both a process and a condition. The process entails the assessment of educational quality and the continued enhancement of educational operations through the development and validation of standards. The condition provides a credential to the public indicating that an institution or a program have accepted and are fulfilling their commitment to educational quality."14

Menurut O' Brian, akreditasi perpustakaan adalah proses jaminan mutu yang dikendalikan oleh standar, kebijakan, dan prosedur padasebuah perpustakaan. Dasarakreditasiperpustakaan yaitu Undang-Undang Nomor 43 Tahun 2007 pasal 18 bahwa setiap perpustakaan dikelolasesuaidenganstandarnasionalperpustakaan. Serta Undang-Undang Nomor 43 Tahun 2007 pasal 23 bahwa setiap sekolah/madrasah menyelenggarakan perpustakaan yang memenuhi standar nasional perpustakaan dengan memperhatikan standar nasional pendidikan.Tujuan adanya akreditasi yaitu untuk meningkatkan kepercayaan masyarakat (pemustaka) terhadap kinerja perpustakaan serta menjamin konsistensi kualitas kegiatan perpustakaan yang bersangkutansertauntuk menjamin terlaksananya layanan perpustakaan yang baik pada setiap satuan pendidikan.Akreditasi dirancang untuk menjamin terpenuhinya standar minimal perpustakaan agar kualitas dari perpustakaan tersebut dapat meningkat.Manfaat akreditasi perpustakaan yaitu untuk meningkatkan motivasi lembaga perpustakaantermasuk sumber daya manusiauntuk meningkatkan kinerjanya.. ${ }^{15}$

Dalam rangka penunjang dan pelaksana Tri Dharma Perguruan Tinggi, penyelenggaraan perpustakaan perpustakaan

${ }_{14}$ http://jimneal.org/2016/02/29/library-school-accreditation/, diakses tanggal 17/09/2016

15 Michael O’Brian, Akreditasi Perpustakaan Sekolah. (Jakarta: Gramedia, 2010) hal. 65 
mencakup bangunan (gedung), perabotan, peralatan (perangkat keras dan lunak, sistem, pengelolaan yang mencakup perencanaan, pengadaan, pendataan, pemanfaatan, pemeliharaan, pengahapusan serta pemutakhiran sarana dan prasarana. Selain itu perguruan tinggi dan program studi harus memiliki pandauan khusus mengenai kelengkapan dan kecakupan sarana dan prasarana yang dibutuhkannya, termasuk sistem klasifikasi,inventarisasi dan informasi keberadaanya. Ini diperlukan untuk menjamin akses yang lebih luas terutama bagi mahasiswa dan dosen. ${ }^{16}$

Akreditasi Perpustakaan PT dasarnya STANDAR NASIONAL PERPUSTAKAAN PT dan Skema Akreditasi Perpustakaan.(Lihat Pedoman Akreditasi Perpustakaan PTPerpusnas) Lembaga Akreditasinya adalah LAP -NAS(Lembaga Akreditasi Perpustakaan- Nasional) lembaga Independen dibawah Perpusnas RI. Instrumennya tidak menggunakan akreditasi BAN PT. BAN-PT utk akreditasi PT yg didalamnya ada pemenuhan stndar sarana dan perpustakaan hanya di dalam sub pertanyaan dalam standar sarana tersebut. Kalau akreditasi perpustakaan mencakup 9 Unsur Perpustakaan. (lihat instrument akreditasi Perpustakaan PT)

Pada bagian ini (Perpustakaan PT terakreditasi) meminta masukkan Prosedur akreditasi dari perpustakaan PT mengajukan akreditasi sampai denganperpustakaan PT terakreditasi (Lihat Pedoman akreditasi Perpustakaan). Perpustakaan terakreditasi di sebuah perguruan tinggi merupakan sebuah simbol ketersediaan penunjang utama bagi berkembangnya keilmuan dan atmosfer akademik bagi civitas akademika di sebuah perguruan tinggi. Sebuah perpustakaan yang telah mengikuti proses akreditasiberarti telah memenuhi standar perpustakaan yang telah ditetapkan oleh Perpustakaan Nasional.

Hasil akreditasi perpustakaan merupakan sebuah gambaran terhadap pemenuhan standar perpustakaan. Hasil akreditasi secara formal ditunjukkan dengan sertifikat kareditasi

${ }^{16}$ http://perpustakaan.unram.ac.id/pentingnya-perpustakaan-diperguruan-tinggi.html, diakses tanggal 17/09/2016 
yang dikirim kira-kira tiga bulan setelah pelaksanaan akreditasi dilaksanakan.Yang terpenting menurut saya adalah sikap kita terhadap hasil akreditasi. Apapun hasil yang diperoleh haruslah menjadi sebuah daya dorong untuk kemajuan perpustakaan. Hasil tersebut harus dipertahankan bahkan terus untuk ditingkakan sehingga secara substansial terjadi peningkatan kualitas perpustakaan. Akreditasi sebagai sebuah tolok ukur sedangkan pelayanan perpustakaan yang merupakan substansi tugas dan tanggung jawab harus terus ditingkatkan. ${ }^{17}$

Meski akreditasi sebuah perpustakaan telah dilakukan, tugas-tugas yang berhubungan dengan perpustakaan hendaknya terus dilakukan. Dengan status yang telah diperoleh, sebagai perpustakaan terakreditasi, tidak berhenti di sana. Justru setelah status diperoleh, terdapat banyak tugas dan upaya yang hendaknya secara kontinu dilakukan.

\section{Tantangan Perpustakaan}

Eksistensi perpustakaan dalam suatu lembaga pendidikan perguruan tinggi merupakan wujud kepedulian pemegang kekuasaan terhadap budaya keilmuan civitas akademika sebuah perguruan tinggi.

Sebagaimana kita maklumi bahwa fungsi perpustakaan adalah: i. Merupakan sumber segala informasi; ii. Merupakan fasilitaspendidikan non-formalkhususnyabagianggotamasyarakat yang tidak sempat mendapatkan kesempatan pendidikan formal; iii. Sarana atau tempat pengembangan seni budaya bangsa melalui buku atau majalah; iv. Keragaman bahan bacaan yang disimpan sehingga perpustakaan juga sekaligus memberikan hiburan bagi pembacanya; v. Merupakan penunjang yang penting bagi riset ilmiah, sebagai bahan acuan dan referensi. ${ }^{18}$

${ }^{17}$ http://perpustakaan.unram.ac.id/pentingnya-perpustakaan-diperguruan-tinggi.html, diakses tanggal 17/09/2016

${ }^{18}$ Bahrul Ulumi, "Institutional Repository Perguruan Tinggi” dalam Jurnal Perpustakaan Libraria, volume 1, Nomor 2, Juli-Desember 2013, hal.246 
Melalui fungsi perpustakaan ini dapat kita ambil sebagai barometer bahwa, realitas perpustakaan yang ada sudahkah memberikan sumber segala informasi?Jika belum, berarti perpustakaan belum bisa mengatasi kebutuhan informasi bagi para pemustaka.

Jika perpustakaan merupakan fasilitas pendidikan nonformal khususnya bagi anggota masyarakat yang tidak sempat mendapatkan kesempatan pendidikan formal, bagaimana realisasinya dalam keseharian?

Bagaimana perpustakaan memberikan peluang sekaligus sarana atau tempat bagi pengembangan seni budaya bangsa melalui buku atau majalah? Jika target tersebut belum juga terpenuhi, maka perpustakaan masih belum fungsional dalam hal pengembangan seni budaya bangsa.

Apakah terdapat keragaman bahan bacaan yang disimpan di perpustakaan yang juga sekaligus memberikan hiburan bagi pembacanya? Keberadaan buku-buku terbitan satu dasawarsa ke belakang menunjukkan bahwa perpustakaan masih sayang pada buku lama dan enggan membeli maupun mengoleksi buku-buku baru yang, mungkin belum banyak beredar di perpustakaan lain.

Hal senada dalam konteks yang berbeda juga ditemukan mengenai problem yang sering muncul di perpustakaan, "College libraries, which are the largest group of libraries in the country, have also been facing the problem of poor services, outdated collection of reading materials, financial constraints and inadequate professional staff."19

Seperti yang telah ditulis oleh Norma Tridiana, bahwa terdapat tanda tanya besar menghantui keberadaan perpustakaan di masa yang akan datang. Apakah perpustakaan secara fisik akan tetap ada di era 20-30 tahun mendatang? Lalu bagaimana bentuk perpustakaan pada masa mendatang? Apakah buku tercetak

\footnotetext{
${ }^{19} \mathrm{http} / / /$ digitalcommons.unl.edu/libphilprac/757/,diakses tanggal
} $17 / 09 / 2016$ 
akan tetap ada di perpustakaan atau tergantikan dengan buku elektronik? ${ }^{20}$

Keberadaan perpustakaan sejak manusia memiliki kebudayaan.Kepunahan perpustakaan tidak perlu dikhawatirkan. Pun, buku-buku yang tercetak yang tersimpan di perpustakaan akan tetap aman dan terjaga, selama perawatan dan penjagaan terus dilakukan secara periodik.Meski kecanggihan teknologi semakin pesat, era digitalisasi yang tidak bisa dipungkiri, namun perpustakaan akan terus menjadi tempat untuk literatur-literatur yang berharga dan penting.

\section{Simpulan}

Perpustakaan perguruan tinggi adalah perpustakaan yang berada pada lingkungan perguruan tinggi atau sekolah tinggi, akademi atau sekolah tinggi lainnya yang pada hakikatnya merupakan bagian integral dari suatu perguruan tinggi. Perpustakaan dapat terakreditasi bilamana telah memenuhi standar-standar yang telah ditetapkan Perpustakaan Nasional dan mengikuti akreditasi perpustakaan, serta mencerminkan kualitas pelayanan sekaligus kelengkapan infrastruktur dan koleksi perpustakaan.Perpustakaan terakreditasi menjadi harapan bagi sebuah perguruan tinggikarena pada tingkatan ini sebuah perguruan tinggi telah memiliki kelengkapan akses keilmuan dan kemudahan dalam membangun atmosfir keilmuan di lingkungan civitas akademika.

${ }^{20}$ Norma Tridiana, "Masa Depan Perpustakaan vs Perpustakaan Masa Depan”, http://bpdadjakarta.net/, diakses tanggal 27/09/2016 


\section{DAFTAR PUSTAKA}

Azizah, "Peran Pustakawan dalam Membangun Citra Perpustakaan PTAIN di Kudus" dalam Jurnal Perpustakaan Libraria, volume 1, Nomor 2, Juli-Desember 2013

Bahrul Ulumi, "Institutional Repository Perguruan Tinggi" dalam Jurnal Perpustakaan Libraria, volume 1, Nomor 1, JanuariJuni 2013.

Wiji Suwarno, PengetahuanDasar Kepustakaan; Sisi Penting Perpustakaan dan Pustakawan. (Bogor: Ghalia Indonesia. 2010).

Michael O’Brian, Akreditasi Perpustakaan Sekolah. (Jakarta: Gramedia, 2010).

Ibrahim Bafadal, Pengelolaan Perpustakaan Sekolah. (Jakarta: Bumi Aksara, 2009).

Norma Tridiana, "Masa Depan Perpustakaan vs Perpustakaan Masa Depan", http://bpdadjakarta.net/, diakses tanggal $27 / 09 / 2016$

Ikhwan, pentingnya perpustakaan di perguruan tinggi, http:// perpustakaan.unram.ac.id/2015/11/10/pentingnyaperpustakaan-di-perguruan-tinggi/ diakses tanggal 29/9/2016.

https://lokanmuko2.wordpress.com/2011/05/17/perananperpustakaan-sebagai-pusat-sumber-belajarpsb/, diakses tanggal 17/09/2016

http://jimneal.org/2016/02/29/library-school-accreditation/, diakses tanggal 17/09/2016

https://en.wikipedia.org/wiki/Library, diakses tanggal 17/09/2016

http://www.anneahira.com/perpustakaan-perguruan-tinggi.htm, diakses tanggal 17/09/2016

http://www.anneahira.com/perpustakaan-perguruan-tinggi.htm, diakses tanggal 17/09/2016

http://ahmadaguskurniawan.blogspot.co.id/2012/12/pengertian- 
perpustakaan-perguruan-tinggi.html, diakses tanggal $17 / 09 / 2016$

http://perpustakaan.unram.ac.id/pentingnya-perpustakaan-diperguruan-tinggi.html, diakses tanggal 17/09/2016

http://bicaraperpustakaan.com/2016/01/definisi-dan-pengertianperpustakaan-perguruan-tinggi.html/, diakses tanggal $17 / 09 / 2016$

https://pustaka.unilak.ac.id/web/detailberita/180, diakses tanggal $17 / 09 / 2016$

http://perpustakaan.unram.ac.id/pentingnya-perpustakaan-diperguruan-tinggi.html, diakses tanggal 17/09/2016

http://digitalcommons.unl.edu/libphilprac/757/, diakses tanggal $17 / 09 / 2016$

http://www.bpkp.go.id/pustakabpkp/index.php?p=wujud\%20 perpus\%20ideal, diakses tanggal 21/09/2016

https://somanybooksblog.com/2011/01/28/the-ideal-library/, diakses tanggal 17/09/2016

http://www.bpkp.go.id/pustakabpkp/index.php?p=perpustakaan\%20 ideal, diakses tanggal 17/09/2016

https://somanybooksblog.com/2011/01/28/the-ideal-library/, diakses tanggal 17/09/2016

http://kober.tripod.com/4.html, diakses tanggal 21/09/2016 http://piqpa.blogspot.co.id/2012/11/pedoman-akreditasiperpustakaan.html, diakses tanggal 17/09/2016

https://sulistyobasuki.wordpress.com/2013/10/27/akreditasiperpustakaan-perguruan-tinggi/, diakses tanggal $17 / 09 / 2016$ 
